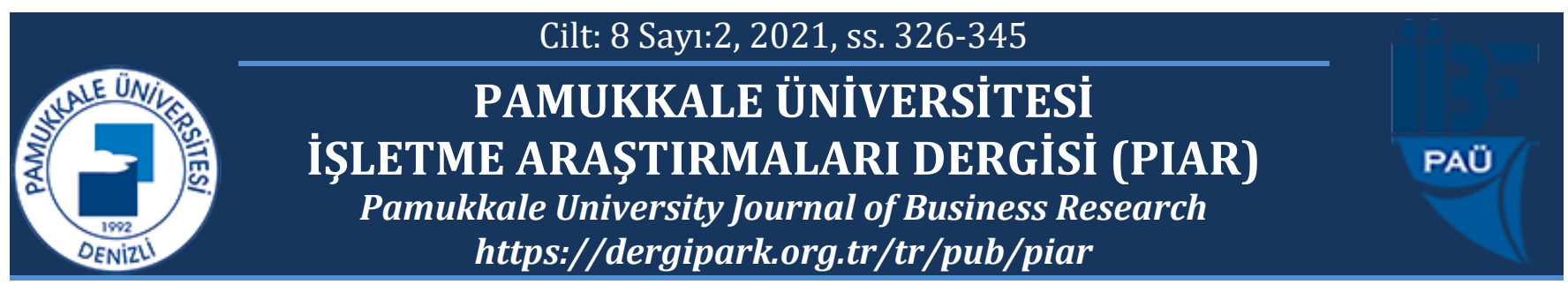

\title{
Covid-19 Pandemisi Döneminde Türkiye'deki Aşk Markalarının Twitter Kapsamında Kelime İlişkilendirme Testi ile Değerlendirilmesi
}

\section{Evaluation of Love Brands in Turkey With Word Association Test in The Scope of Twitter During The Coronavirus Period}

\section{Esen ŞAHIN ${ }^{*} \quad$ Mehnur BAŞTOPUZ²}

\author{
${ }^{1}$ Selçuk Üniversitesi İktisadi ve İdari Bilimler Fakültesi, esenboztassahin@gmail.com, https://orcid.org/0000-0001-7215- \\ 5018 \\ 2 Selçuk Üniversitesi Sosyal Bilimler Enstitüsü, m.bastopuz@gmail.com, https://orcid.org/0000-0001-8498-1181 \\ *Yazışılan Yazar/Corresponding author
}

Makale Geliş/Received: 18.08.2021

Öz

21. yüzyılın ilk çeyreğinde ortaya çıkan Covid-19 virüsü, küresel ölçekte yarattı̆̆ oluşmasına neden olmuştur. Tüketicilerin istek ve ihtiyaçları bu değiş̧imden önemli oranda etkilenmiştir. Bu bağlamda araştırmada tüketicilerin aşk markalarına olan tutumları incelenmiştir. Çalışmanın amacı, Covid19 pandemisi öncesi ve pandemi sürecinde oluşan aşk markaları listesini değerlendirmek, meydana gelen değişimlerin nedenlerini araştırmak amacıyla analizler yapmaktır. Araştırma sorularından bazıları; "Pandemiyle değişen yaşam koşullarında tüketicilerin aşk markaları değişmiş midir?", "Tüketiciler aşk markaların Twitter'da konuşurken sıklıkla kullandıkları kelimeler nelerdir?" şeklindedir. Araştırma soruları MAXQDA 2020 analiz programı ile değerlendirilmiş, Kelime Iliş̧kilendirme Testi (KİT) Nitel Araştırma Yöntemiyle kelime bulutu, kod bulutu ve kod dağ̊tım modeli analizleri yapılmıştır. Analizler sonucunda, Covid-19 pandemisine rağmen değişmeyen aşk markalarının yanında bu süreçte değişen ve yeni döneme uyum să̆layan aşk markalarının da olduğu tespit edilmiştir. İçerik analiziyle elde edilen araştırma bulgularının ayrıntılı açıklaması yapılmıştır.

Anahtar kelimeler: Marka, Marka Aşkı, İçerik Analizi, Kelime İlişkilendirme Testi (KİT), Twitter

JEL kodlarn: M31
Makale Kabul/Accepted: 17.09.2021

\begin{abstract}
Corona virüs, which emerged in the first quarter of the 21st century caused a new lifestyle to emerge with its global effects. Consumers desires and needs have been significantly affected by this change. In this context, the attitudes of consumers towards love brands were examined in the study. The aim of the study is to evaluate the list of love brands that occurred before the Covid-19 pandemic and during the pandemic period and to conduct analyzes to investigate the reasons for the changes that occurned. Some of the research questions are; "Have the brands of love of consumers changed under the changing life conditions with the pandemic?", "What are the words that consumers frequently use when talking about love brands on Twitter?" in the form. The research questions were evaluated with the $M A X Q D A 2020$ analysis program and the word cloud, code cloud and code distribution model analyzes were performed within the scope of the Word Association Test (WAT) Qualitative Research Method. As a result of the analysis, it was determined that there are love brands that have changed and adapted to the new era in addition to the love brands that have not changed despite the Covid-19 pandemic. Detailed explanation of the research findings obtained through content analysis was made.
\end{abstract}

Keywords: Brand, Brand Love, Content Analysis, Word Association Test, Twitter

JEL codes: M31 


\section{GíRiş}

Marka; logo, sembol, isim, renk gibi somut ve kişilik, imaj gibi soyut bileşenleri barındıran bir kavramdır. Bu bağlamda hem somut hem de soyut bir kavram olan marka; dinamik, yaşayan ve esnek yapıda ve insanlar üzerinde etki bırakabilmesi için birtakım özelliklere sahip bir bütündür. İnsanları markaya çekme noktasında marka bileşenleri içerisinde sadakat, bağl1lık, güven gibi kavramlar olmazsa olmaz unsurlar olsa da bunlar günümüz koşullarında sürdürülebilir marka değeri yaratmada yeterli olamamaktadır. Aşk kavramı genel kullanım açısından da bir kavram olması sebebiyle bu söz konusu bileşenlerin kapsam bağlamında üzerinde konumlanmaktadır. Çünkü markalar, kişileştikçe tüketici-marka ilişkisi oluşturma noktasında daha ilişkili, etkili ve belirgin hale gelmektedir (Ramadan, 2019: 706).

Tüketiciler tarafından bir markanın tercih edilmesinde önemli bir unsur haline gelen marka aşkı, tüketici ile marka arasındaki ilişkiye ve etkileşime farklı bir boyut kazandırmıştır. Marka aşkı, tüketicinin markaya tutkuyla bağlanmasını sağlayan, markanın kişiliğini ön plana çıkaran, tüketicilerin sadakat düzeyini güçlendiren yapıda sadık olmasını sağlayan bir kavramdır. Türkiye'de her yıl düzenli olarak MediaCat dergisi tarafından aşk markaları seçilmektedir. Güvenilir ve şeffaf bir veri kaynağı olması ve amaç ile örtüşen içeriğe sahip olması, farklı ilgi gruplarına ve alanlara içerik sunabilen büyük bilgi platformu olması nedenleri ile MediaCat Aşk Markası Listeleri çalışmada veri kaynağı olarak kullanılmıştır.

Tüm dünyayı etkisi altına alan Covid-19 pandemisi pek çok alanda yarattığı etkilerin yanı sıra aşk markaları bağlamında da etkiler yaratmıştır. Fakat bu etkiye maruz kalmayan markalar da bulunmaktadır. Dolayısıyla Covid-19 pandemisi öncesi ve sonraki süreçte aşk markaları listesinde yer alan, sıralamaları değişmeyen, değişen veya farklı kategoride listelere eklenen aşk markalarına dair incelemeler yaparak değerlendirmelerde bulunmak çalışmanın ana amacıdır. Bu amacı gerçekleştirmek için MAXQDA 2020 analiz programı tercih edilmiş, Kelime İlişkilendirme Testi (KİT) Nitel Araştırma Yöntemi kapsamında kelime bulutu, kod bulutu ve kod dağıtım modeli analizleri yapılmıştır. Yapılan bu analizler ile tüketicilerin Twitter sosyal medya platformu kapsamında aşk markalarına dair yaptıkları yorumlarında en fazla kullandıkları kelimeleri görselleştirmek ve kod bulutu ile kavramlar arası bağlantıyı açıklamak amaçlanmıştır. Kod dağıtım modeli ile incelenen aşk markaları arasında tüketici bakış açısı bağlamındaki farkı görmek ise çalışmanın diğer bir amacıdır.

\section{KAVRAMSAL ÇERÇEVE}

Marka, üreticilerin mal veya hizmetlerini tanıtmak, rakiplerden ayırt edilmesini sağlamak için kullanılan isim, logo, sembol, renk, sözcük, kavram, tasarım, resim ve tüm bu unsurların birleşmesiyle meydana gelen soyut ve somut bir kavramdır. Her ne kadar kelime anlamı olarak logo, sembol, renk, isim gibi unsurlardan meydana gelse de marka işletmeyi temsil eden güçlü ve etkili bir kişiliğe de sahiptir (İslamoğlu ve Fırat, 2016: 8-9). Marka kavramı birçok araştırmacı tarafından farklı şekillerde tanımlanmıştır. Amerikan Pazarlama Derneği (American Marketing Association - AMA)'ne göre marka, “bir satıcının malını veya hizmetini diğer satıcılardan farklı olarak tanımlayan bir ad, terim, tasarım, sembol veya başka bir özellik"tir (AMA, 2017). Sammut ve Bonnici (2015) tarafından marka, "işletme, kişi, mal veya hizmet için farkındalık, kimlik ve itibar oluşturma maksadıyla tasarlanan bir dizi 
somut ve somut olmayan özelliklerdir" şeklinde tanımlanmıştır. Bir marka sadece logo, isim, renk veya kelimeden ibaret değildir. Bu boyutların çok daha ötesinde insanların kendilerini başkalarına kıyasla daha farklı hissetmelerini sağlayan bir enerjinin sembolüdür (Aktuğlu, 2016: 2). Diğer bir ifade ile marka, bir isimden ziyade tüketicilerin hayal gücüne bağlı olarak istekleriyle şekillenen ve ürüne bir kişilik katan işletme varlığıdır (Can, 2007: 225).

Yukarıda yapılan tanımlar incelendiğinde markanın kavramsal çerçevesi oluşturulurken en çok vurgu yapılan özelliğin markanın dikkat çekmesi yani rakiplerinden ayırt edici özelliğe sahip olması olduğu görülmektedir. Rekabetin kurallarının değiştiği ve etkilerinin giderek arttığ1 günümüz koşullarında markalar ayakta kalma, güçlü olma, sürdürülebilir bir yapıya kavuşma ve rakiplerinden daha üstün olmanın yollarını aramaktadır. Markalar tüketicilerinin gözünde ve kalbinde, rakiplerinden daha farklı bir konumda olabilmek için kendilerine âşık tüketici profili oluşturmayı hedeflemektedir. Eğer tüketiciler markalarına âşık olurlar ise bu âşık tüketiciler sadık tüketicilere göre ilişki halinde oldukları markalardan daha zor vazgeçeceklerdir. Markaların marka aşkı kavramının üzerinde durmalarının diğer sebebi, aşk duygusuyla birlikte oluşan aşk markalarının rakiplerinden üstün olma fırsatını yakalamış olmalarıdır (Özbek ve Doğan, 2018: 269).

Marka aşkı kavramının doğuşuna ve akademik çalışmalar bağlamında ilgi uyandırmasına öncülük eden isimlerden olan Carrol ve Ahuvia (2006)'e göre marka aşkı, müşteri ile marka arasında yaşanan duygusal ve tutkulu bağdır. Bu alandaki bir diğer öncü isim ise, Saatchi \& Saatchi işletmesinin CEO'su, Kevin Roberts'tir. Roberts tarafından 2004 yılında yazılmış "Lovemarks" isimli kitapta kavrama yer verilmiştir. İlgili kitapta Roberts, aşkın gizem, duygusallık ve samimiyet olarak üç temel bileşenden oluştuğunu belirtmektedir. Tüketicide saygı ve sevgi çerçevesinde bu üç bileşen meydana gelirse marka aşkı oluşabilecektir (Roberts, 2005).

Sternberg (1986) çalışmasında hem sevginin doğasına hem de farklı ilişkilerdeki aşk yapısına ait üçgen bir aşk teorisi sunmaktadır. Bu teori; yakınlık, tutku ve karar olmak üzere üç bileşenden oluşmaktadır. Kişilerarası aşk teorisi, psikolojiden pazarlamaya kadar merkezinde insan olan pek çok farklı araştırma alanına uyarlanmıştır (Çavuşoğlu ve Demirbağ, 2020: 1068). Marka aşkı üzerine yapılan pek çok araştırmanın temelinde, kişilerarası aşk teorisi yatmaktadır. Kişilerarası aşk teorisi pazarlama bağlamında kullanıldığı taktirde marka aşkı kavramı ortaya çıkmaktadır (Zengin ve Aladağ, 2018: 23). Çünkü âşık olduğunu düşünen kişide "başkalarının değil benim olmalı" düşüncesi hakimdir. Bu düşünce ile âşık olduğu nesneye yaklaşmakta ve beklenmeyen bir güç kullanarak ona sahip olma arzusu yaşamaktadır (Ayvaz, 2017: 160). Marka aşkı, tüketicilerin bir markaya olan tutkusunu yansıtmaktadır (Zhou vd., 2020: 1). Diğer bir ifade ile, tüketici ve marka arasında meydana gelen duygusal bağın şiddetidir (Onurlubaş ve Altunışık, 2019: 117).

Tüketicilerin aşk markalarına dair geliştirdikleri duygular aşağıdaki özellikleri içermektedir (Albert vd., 2008: 1064):

- Markaya karşı tutkulu olmak,

- Markaya bağlı olmak, 
- Marka hakkında olumlu değerlendirme yapmak,

- Markaya olumlu duygular beslemek,

- Markaya fazla sevgi göstermek.

Yukarıda yer alan tüketicilerde aşk markalarına dair gelişen duygular tüketicilerin aşk markalarına olan sevgisi ve bu sevginin hangi etkileri içerdiğine dair bir çerçeve oluşturmaktadır. İlgili markaya karşı duyulan sevgi, aşk markalarını etkilediği gibi insanlar arasındaki ilişkiyi de etkilemektedir. Marka aşkına sahip olan tüketicilerin tüm ilişkilerinde daha sadık oldukları ve insan ilişkilerindeki diyaloglarda da daha pozitif olduğu düşünülmektedir (Çavuşoğlu ve Demirbağ, 2020: 1074). Marka aşkına sahip tüketiciler daha hoşgörülü bireylerdir. Söz konusu bu durum, "aşkın gözü kördür" etkisi yaratmakta ve markaya âşık tüketicinin aşk markası kusurlu bir ürünü tüketiciyle buluştursa dahi tüketici bu hatanın dolaylı olarak gerçekleştiğine inanma eğilimindedir (Zhang vd., 2020: 3).

Marka aşkı kavramı, duygular bağlamında kişiler arası yaşanan aşkın tüketiciler ve markalar boyutuna kayması sonucunda ortaya çıkan kavramdır. Yani tüketiciler, kişiler arasında yaşanan duygular gibi markalarla da özel ve etkili duygusal ilişkiler yaşayabilmektedir. Yapılan tanımlarda marka aşkının öznesi hep tüketici olmuştur. Oysa ki, markaların kendi aralarında oluşan etkiler de bulunmaktadır. Çünkü marka bünyesinde oluşan aşk duygusu tüketicileri etkilediği ölçüde markalar arası rekabeti de etkileyebilecektir.

\section{TASARIM VE YÖNTEM}

Birçok araştırmacıya göre farklı şekillerde tanımlanan marka kavramında en temel nokta markaların ayırt edici özelliğini öne çıkartmaya yapılan vurgudur. Çünkü markaların rakip markalardan ayırt edici, tüketicinin zihninde ve kalbinde yer edebilecek strateji ve özelliklere sahip olması gerekmektedir. Tüketicilerin zihninde ve kalbinde olmayı sağlayacak en etkili araç son yıllarda sosyal medyadır (Şayan, 2020: 321). Sosyal medya platformları üzerinde markalar başarılı pazarlama stratejileri sürdürebilmekte ve hedef kitlelerine etkili ve hızlı bir biçimde ulaşarak kendilerini çok rahat ifade edebilecekleri iletişim ortamlarına kavuşabilmektedir. Sosyal medya platformları aynı zamanda tüketicilerin de kendilerine ait duygu ve düşüncelerini rahatça ifade edebilecekleri ve markaların sosyal kimliklerine katkı sağlayabilecekleri bir ortamdır (Tran vd., 2020: 3). Tüketicilerin markadan istediklerini ve beklediklerini rahat ve hızlı bir biçimde ifade edebildikleri sosyal medya platformlarından biri olan Twitter, küresel ölçekte gün geçtikçe giderek daha fazla kişi tarafından tercih edilmektedir (Jansen vd., 2009: 2173). Twitter, markaların güvendiği, benimsediği ve farklı kitlelerle etkili iletişim kurabildiği sosyal bir ortamdır. Markalar Twitter sayesinde hem marka hesaplarını takip eden müşterilerine hem de bir hashtag (etiket) yardımı ile daha büyük tüketici kitlesine ulaşabilmektedir (Edman, 2010: 46). Daha önce marka aşkı ile yapılan bir çalışma (Şayan, 2020) Instagram sosyal medya platformu üzerinden gerçekleştirilmiştir. Çalışmanın içerik analizi kapsamında uygulanacak olan kelime bulutu, kod bulutu ve kod dağıtım modeli analizlerinin bu platformdan çekilen verilerle etkili bir biçimde görselleştirilebilmesi, çalışmada kullanılacak veri seti içeriğine uygun yapıda bir içeriğe sahip olan bir platform olması, geniş kitlelerce tercih edilmesi, sosyal medya pazarlamasında etkin bir sosyal medya platformu olması ve literatüre farklı örneklem 
üzerinden gerçekleştirilmiş bir çalışma ile katkı sağlamak gibi nedenlerle çalışma; Twitter sosyal medya platformu üzerinden yürütülmüştür.

Çalışmada nitel araştırma yöntemlerinden betimsel araştırma türü kullanılmıştır. Nitel yöntem, yapısı gereği objektifinden ziyade daha çok duygusal ve kavramsal cevaplar ile ilgilenmektedir (Karataş, 2015: 65). Strauss ve Corbin'e göre nitel yöntemde analiz sürecini kodlama oluşturmaktadır. Kodlama süreci kavramsallaştırma ile başlamaktadır. Araştırmanın konusu ile ilgili elde edilen verilerden yola çıkarak, araştırmacı "bu veri neyin parçasıdır?", “bu veri neyi simgelemektedir?", “bu veride gizli olan anlam nedir?" gibi sorulara cevap aramaya ve o veriyi etiketlemeye çalışmaktadır (Aktaran: Gürbüz ve Şahin, 2018: 434-435).

Covid-19 pandemisi ve aşk markaları temelinde literatürde yapılan çalışmalar incelenmiş ancak her iki durumun birlikte değerlendirildiği bir çalışmaya rastlanmamıştır. Aşk markaları kapsamında yürütülen araştırmalarda ağırlıklı olarak nicel araştırma yöntemlerinden biri olan anket tekniği kullanılmıştır. Dolayısıyla çalışma kapsamında; literatürdeki açığı gidermek, alana değer ve katkı sağlamak amacıyla Covid-19 pandemisi döneminde aşk markaları incelenmesi çalışmanın önemini ortaya koymaktadır. Literatür incelendiğinde konu ile ilişkilendirilebilecek farklı çalışmalar (Deniz, 2020; Arslan ve Karagül, 2020; Çakıroğlu vd., 2020; Budak ve Korkmaz, 2020, Duygun, 2020; Bairrada vd., 2019; Zhang vd., 2020; Joshi ve Garg, 2021; Kumar vd., 2021) tespit edilse de aşk markalarını Covid-19 pandemisi öncesi ve sonrası süreçte pozisyonları bağlamında ilişkilendirerek inceleyen bir çalışma bulunmamaktadır. Bu durum da çalışmanın özgünlüğünü ortaya koymaktadır.

İlk kez 2007 yılında gerçekleştirilmesinin ardından 2009 yılından günümüze kadar her yıl düzenli olarak MediaCat Dergisi önderliğinde, Ipsos Danışmanlık Şirketi tarafından araştırma sürecinin yönetildiği bir kapsamda Türkiye'nin aşk markaları belirlenmektedir. Türkiye'nin lider pazarlama dergisi MediaCat, 1993 yılında aylık olarak yayımlanmaya başlamıştır. Dergi; bünyesinde 2002' den bu yana gerçekleştirilen çeşitli sektörel eğitimler, yarışmalar, etkinlikler, ek yayınlardan kitaplara kadar farklı stratejiler ile pazarlama iletişimi alanında sektörel bazda içerik üreten bilgi platformu haline gelmiştir (tr.wikipedia.org). Farklı ilgi gruplarına ve alanlara içerik sunabilen büyük bilgi platformu olması, güvenilir ve şeffaf kurumsal yapılanması gibi nedenlerle çalışmada MediaCat dergisi veri kaynağı olarak tercih edilmiştir. Covid-19 virüsünün etkisiyle pandemi yılı olan 2020'de seçilen aşk markalarında önceki yıllara kıyasla birtakım değişiklikler gözlemlenmiştir. Örneğin, daha önceki yıllarda listede yer almayan dijital tv platformu, online alışveriş sitesi gibi farklı kategoriler 2020 yılında listede yer almıştır. 2019 yılının Aralık ayında Çin'in Wuhan bölgesinde ortaya çıkan ve tüm dünyayı etkisi altına alan Covid-19 virüsü ve ardından gelen pandemi süreci hem toplumsal hem de ekonomik anlamda küresel değişikliklerin yaşandığı bir dönemi temsil etmektedir. Bu süreçte 'hayat eve sığar' ve 'evde hayat var' sloganları ile insanların sosyal yaşamdan uzaklaşarak evlerine kapanmaları istenmiş ve kimi dönemlerde bu kapanmalar yasal bir zorunluluk haline dönüştürülmüştür. Zorunlu kalmadıkça evden çıkmamaları doğrultusundaki telkinlerle karşı karşıya kaldıkları bir dönemde tüketicilerin yaşam tarzlarında elbette önemli değişiklikler de varolagelmiştir. Alışverişlerin büyük bir kısmı online olarak evden çıkmadan yapılmaya başlanmıştır. 
$\mathrm{Bu}$ açıklamalar kapsamında araştırma soruları şu şekilde belirlenmiştir:

Pandemiyle değişen yaşam koşullarında tüketicilerin aşk markaları değişmiş midir?

Pek çok marka pandemiden olumsuz etkilenirken pandemi yılında aşk markası listesinde önceki konumunu korumayı ve yeni yılda aşk markası olmayı başaran markalar bu başarıyı nasıl elde etmiştir?

Tüketicilerin aşk markalarını Twitter'da konuşurken sıklıkla kullandıkları kelimeler nelerdir?

Araştırmanın evreni MediaCat tarafından belirlenen 2019 ve 2020 yılına ait aşk markalarından oluşmaktadır. Araştırmanın örnekleminin belirlenmesinde olasılıklı olmayan örnekleme yöntemlerinden amaçlı örnekleme yöntemi kullanılmıştır. Amaçlı örnekleme, araştırmacının araştırma sorunsalına uygun geldiğini düşündüğü ve belirli özellikleri taşıyan deneklerin seçildiği örneklemdir. Diğer bir ifade ile, araştırmacının amacına en uygun birimlerin örnekleme dahil edilme sürecidir (Gürbüz ve Şahin, 2018: 132). Bu çalışma kapsamında bir haftalık örnekleme döneminde 4 markanın Twitter resmi sayfasına tweet atan tüketicilerin tweetleri ele alınmıştır. Her bir marka için tüketicilerin tweetleri $(n=500)$ üzerinden analizler gerçekleştirilmiştir. Bu çalışmada kullanılan kodlama yöntemi, Louisiana Üniversitesi'nde Haley Edman'ın (2010) “Twittering to the Top: A Content Analysis of Corporate Tweets to Measure Organization-Public Relationships - Zirveye Twitterlaşma: Organizasyon-Kamu İlişkilerini Ölçmek için Kurumsal Tweetlerin İçerik Analizi” başlıklı tezde kullandığı 11 farklı kodlama kategorisindeki dördüncü kodlama kategorisinden uyarlanmıştır. Bu kodlama tweet türünü ifade etmektedir. Tweetlerin içeriği üçe ayrılmaktadır; orijinal gönderi, retweet veya yanıt. Orijinal gönderi, markanın kendi gönderdiği tweetleri ifade etmektedir. Retweet, markaların gönderdiği tweetleri takipçilerin kendi sayfalarında paylaşmasıdır. Yanıt ise, tüketicilerin tweetlerinde markanın ismini etiketleyerek kendini ifade etme şeklidir. Çalışma kapsamında tüketicilerin aşk markalarına olan tutumları incelendiği için markalar tarafından oluşturulan orijinal metinler analize dahil edilmemiştir.

Çalışmada içerik analizinden elde edilen verileri görselleştirerek daha anlaşılır hale getirmek maksadıyla kelime bulutu tekniği kullanılmıştır. Kelime bulutu, analiz edilen verilerde tekrar eden kelimelerin sıklığını ifade eden özel bir görselleştirme tekniğidir. Böylece araştırmacı, araştırması kapsamında elde ettiği verilerini ve yaptığı analizlerinin sonuçlarını okuyuculara çok daha anlaşılır görsel temelli bir içerikle sunma imkanı elde etmektedir (Williams vd., 2013: 45). Görselleştirmenin amacı estetik açıdan güzel görünmesini sağlamak değil, anlaşılır olmasını sağlamaktır.

MediaCat dergisinin önderliğinde Ipsos Danışmanlık Şirketi tarafından gerçekleştirilen Türkiye'nin Lovemark (Aşk Markası) araştırmasının araştırma sahası 2019 ve 2020 yılı için Şubat-Haziran ayları dönemidir. Türkiye temsili kadın erkek dağılımı eşit olmak üzere iki bin katılımcının dahil edildiği çalışmalarda 2019 yılı için Bilgisayar Destekli Telefon Görüşmesi (CATI) yöntemi kullanılarak Lovemark analizi gerçekleştirilirken, 2020 yılında bu analize ek olarak Bilgisayar Destekli Web Görüşmesi (CAWI) yöntemleri kullanılarak

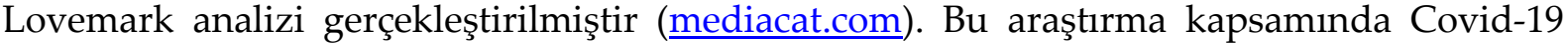


pandemi öncesi ve pandemi sürecine ait seçilen aşk markalarının listeleri aşağıda Tablo 1'de gösterilmektedir.

Tablo 1. Covid-19 Pandemi Öncesi ve Pandemi Sürecinde Seçilen Aşk Markaları

\begin{tabular}{|c|c|}
\hline \multicolumn{2}{|c|}{ Türkiye'nin Aşk Markaları (Lovemark) } \\
\hline 2019 Yilı (Pandemi Öncesi) & 2020 Yılı (Pandemi Süreci) \\
\hline Akaryakıt İstasyonu: OPET & Ambalajlı Su: Erikli \\
\hline Ambalajlı Su: Erikli & Banka: Ziraat Bankası \\
\hline Banka: Ziraat Bankası & Cam Eşya: Paşabahçe \\
\hline Beyaz Eşya: Arçelik & Dijital TV Platformu: Netflix \\
\hline Bilgisayar: Casper & Diş Macunu: Colgate \\
\hline Bulaşık Deterjanı: Fairy & El Kremi: Arko Nem \\
\hline Cep Telefonu: Samsung & Havayolu Şirketi: Türk Hava Yolları \\
\hline Futbol Takımı: Galatasaray & Kahve: Nescafe \\
\hline Giyim - Tekstil: LC Waikiki & Kişisel Bakım Marketi: Gratis \\
\hline GSM Operatörü: Turkcell & Online Alışveriş Sitesi: Trendyol \\
\hline $\begin{array}{l}\text { GSM Operatörü Özel Mobil Uygulama: } \\
\text { Vodafone Yanımda }\end{array}$ & Sosyal Medya Platformu: Instagram \\
\hline Kahve: Nescafe & Spor Ayakkabı: Adidas \\
\hline Makyaj: Avon & Şampuan: Elidor \\
\hline Otomotiv: Volkswagen & Tıraş Bıçă̆ı: Gillette \\
\hline Paketli Kuruyemiş: Tadım & Tv Kanall: FOX \\
\hline Sosyal Medya Platformu: Instagram & \\
\hline Süpermarket: Migros & \\
\hline
\end{tabular}

Kaynak: mediacat.com, Erişim: 15.03.2021.

Yukarıdaki tabloda yer alan aşk markaları incelendiğinde Covid-19 pandemisine rağmen değişmeyen dört marka tespit edilmiştir. Bunlar: Erikli, Ziraat Bankası, Nescafe ve Instagram'dır. Çalışmanın amacına uygun olarak bu dört marka analize dahil edilmiştir. Tüketicilerin değişen yaşam tarzlarıyla ilişki olarak listede yer alan Online Alışveriş Sitesi Trendyol ve Dijital Tv Platformu Netflix markası amaçsal örnekleme yöntemine göre seçilmiştir. Ziraat Bankası $(n=500)$ ve Trendyol $(n=500)$ markası için incelenen tweetler kapsamında yer alan ifadeler ağırlıklı olarak markaya karşı duyulan kırgınlık ile şikayet 
içerikli mesajlar olması ve marka aşkı için oluşturulan kod listesindeki herhangi bir kod ile uyumlu olmamasından dolayı bu iki markanın analizden çıkarılması uygun görülmüştür. Çalışma kapsamında incelenen aşk markalarının son hali Tablo 2' de verilmiştir.

Tablo 2. Çalışma Kapsamında İncelenen Aşk Markaları

Ambalajlı Su: Erikli

Kahve: Nescafe

Sosyal Medya Platformu: Instagram

Dijital TV Platformu: Netflix

Ele alınan dört markaya nitel araştırma deseninden biri olan içerik analizi uygulanmıştır. İçerik analizi, metinsel veriler, görsel veriler ve ses verileri olmak üzere çok çeşitli veri kaynakları için kullanılabilen bir yöntemdir (Stemler, 2015: 1). İçerik analizi kapsamında kelime bulutu, kod bulutu ve kod dağıtım modeli oluşturulmuştur.

\section{BULGULAR VE TARTIŞMA}

Kodlama aşamasında literatürde konuyla ilgili anahtar kelimeler seçilerek kod listesi oluşturulmuştur. Oluşturulan kod listesi MAXQDA 2020 nitel analiz programına aktarılmıştır. MAXQDA 2020, kalitatif ve karma yöntem araştırmaları için kullanılan bir yazılım programıdır. MAXQDA 2020 paket programı, metin belgesi, pdf dosyası, resim, web site, ses ve kayıt videoları, SPSS veri dosyası, odak grup tartışması, YouTube yorumları ve Twitter gibi sosyal medya platformlarından verileri toplama imkanı sağlayan ve bu veriler üzerinde görselleştirme gibi farklı analiz yapma imkanı sağlayan bir kapsamdadır (maxqda.com). MAXQDA 2020 nitel analiz programı ile kelime sıklığını sorgulamak amacıyla kelime bulutları oluşturulmuştur. MAXQDA 2020 programı aracılığıyla Twitter üzerinden giriş yapılarak markaların tweetlerine ulaşılmıştır. İncelenen 4 markaya ait oluşturulan kelime bulutları aşağıda sırasıyla yer almaktadır.

\subsection{Erikli}

Uygulanacak kelime bulutu analizi ile Erikli markasının tüketiciler perspektifinden Twitter' da hangi kelimeler kullanılarak ifade edildiği ve bu kelimelerin ne kadar sıklıkla kullanıldığını belirlemek hedeflenmektedir. Şekil 1'de Erikli markasının kelime bulutu yer almaktadır. 


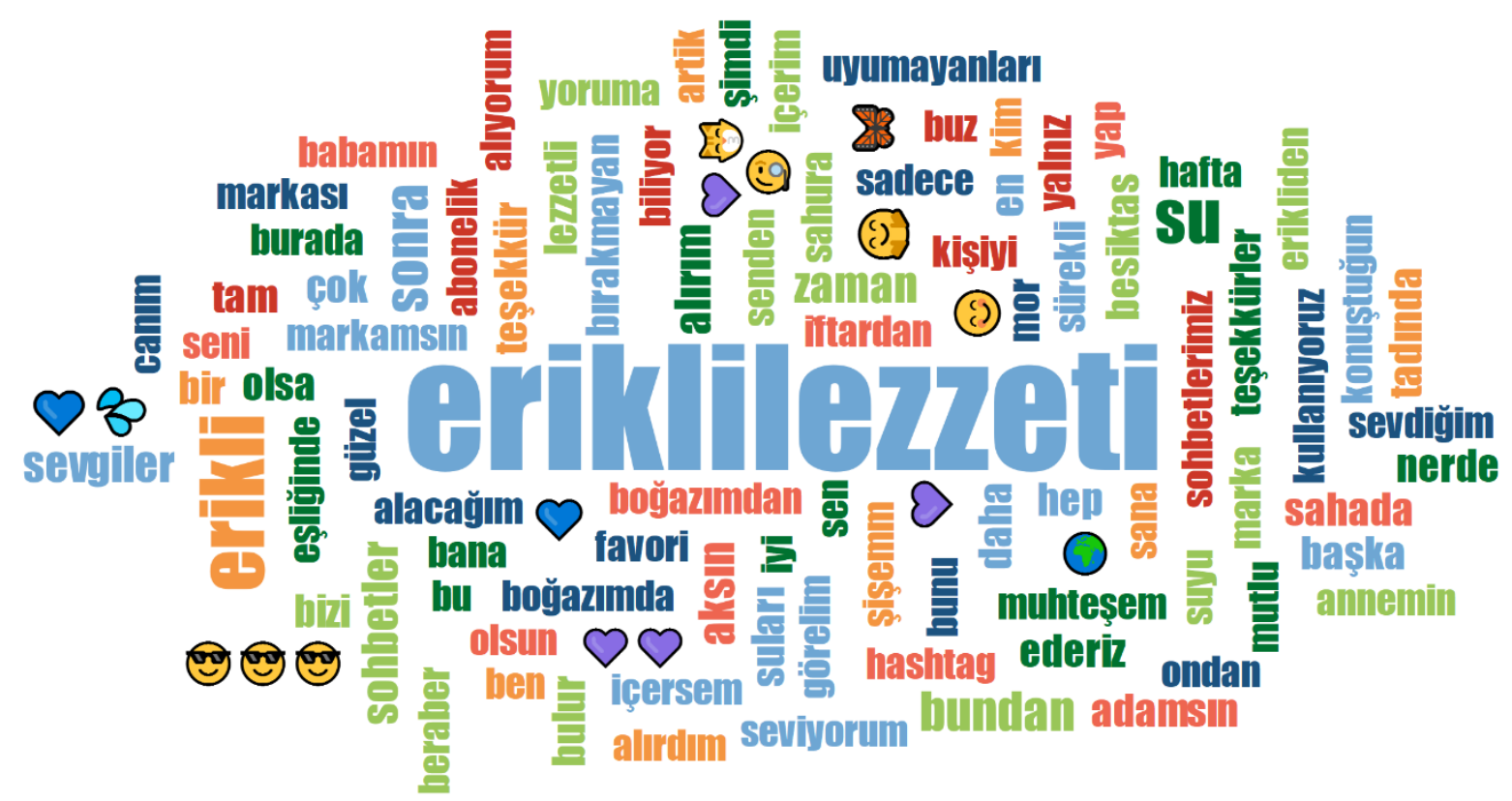

Şekil 1. Erikli Markasının Tüketicileri için Oluşturulan Kodlar ile İlişki Kurdukları Kelimelerin Frekans Değerlerine Göre Kelime Bulutu Görseli

Erikli markası için tüketicilerin en çok tekrar ettiği 10 kelime; eriklilezzeti $(f=463)$, erikli $(f=174)$, su $(f=108)$, sonra ( $f=55)$, bundan $(f=47)$, sevgiler $(f=29)$, sohbetler $(f=29)$, olsa $(f=22)$, teşekkür ( $\mathrm{f}=18$ ) ve lezzetli $(\mathrm{f}=14)$ olarak belirlenmiştir. Tüketicilerin marka aşkıyla ilgili kodlar ile ilişki kurduğu kelimelerin frekans değerleri parantez içinde belirtilmiştir. Parantez içinde belirtilen frekans değerleri, kelimelerin o sayı kadar vurgulandığını ifade etmektedir. Kod listesinde yer alan kodlar tweetlerin içeriğine göre kodlanmıştır. Kelime bulutu incelendiğinde bir aşk markası olan Erikli'nin tüketicilerin kalbinde yer almayı başardığı şeklinde değerlendirme yapılabilmektedir. En çok tekrar edilen kelimeler içerisinde "bundan" ve "sonra" kelimeleri anlamsız kelimeler olarak görülmektedir. Fakat o kelimelerinin en çok tekrar edilmesinin sebebi, 'bundan sonra hep erikli içeceğim' içerikli çok fazla tweetin yer almasından kaynaklanmaktadır. Kalitesinin hiç değişmediğine vurgu yapan ve bundan sonra hep Erikli alacağını ifade eden tweetlere çok fazla rastlanması müşteri memnuniyetini gösterdiği gibi Erikli markasının bu tehdit içerikli Covid-19 pandemisi durumundan olumsuz yönde etkilenmediğinin de göstergesidir.

\subsection{Nescafe}

Uygulanacak kelime bulutu analizi ile Nescafe markasının tüketiciler perspektifinden Twitter'da hangi kelimeler kullanılarak ifade edildiği ve bu kelimelerin ne kadar sıklıkla kullanıldığını belirlemek hedeflenmektedir. Şekil 2'de Nescafe markasının kelime bulutu yer almaktadır. 


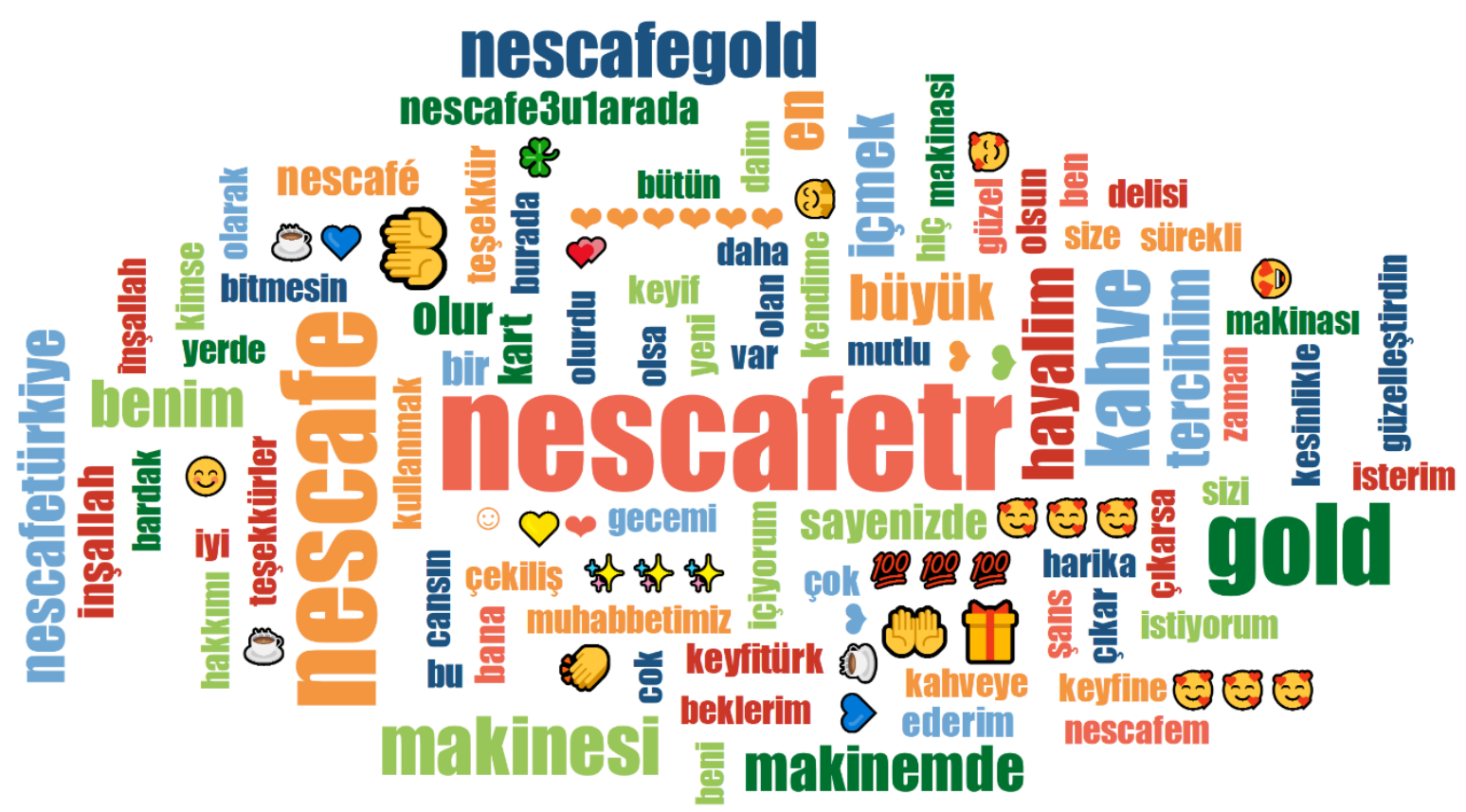

Şekil 2. Nescafe Markasının Tüketicileri için Oluşturulan Kodlar ile İlişki Kurdukları Kelimelerin Frekans Değerlerine Göre Kelime Bulutu Görseli

Nescafe markası için tüketicilerin en çok tekrar ettiği 10 kelime; nescafetr ( $f=609$ ), nescafe $(\mathrm{f}=482$ ), gold $(\mathrm{f}=393)$, kahve $(\mathrm{f}=272)$, makinesi (255), nescafegold $(\mathrm{f}=194)$, hayalim $(\mathrm{f}=170)$, benim ( $\mathrm{f}=148)$, tercihim $(\mathrm{f}=138)$ ve makinemde $(\mathrm{f}=133$ ) olarak belirlenmiştir. Tüketicilerin marka aşkıyla ilgili kodlar ile ilişki kurduğu kelimelerin frekans değerleri parantez içinde belirtilmiştir. Parantez içinde belirtilen frekans değerleri, kelimelerin o sayı kadar vurgulandığını ifade etmektedir. Kod listesinde yer alan kodlar tweetlerin içeriğine göre kodlanmıştır. Kelime bulutu incelendiğinde bir aşk markası olan Nescafe'nin tüketicilerin kalbinde yer almayı başardığı şeklinde değerlendirme yapılabilmektedir. Nescafe, Twitter üzerinde sürpriz etkinlikler ile belli aralıklarla çekiliş düzenlemektedir. Çekilişin heyecanı ile tüketicilerin markaya karşı daha samimi tweetler attığı gözlemlenmiştir. Böylece markayı takip etmeyen farklı kişi ve gruplara da ulaşma fırsatı yaratılmaktadır. Sonuç olarak, Nescafe markası bu tehdit içerikli Covid-19 pandemisi durumundan olumsuz yönde etkilenmediğini göstermektedir.

\subsection{Instagram}

Uygulanacak kelime bulutu analizi ile Instagram markasının tüketiciler perspektifinden Twitter'da hangi kelimeler kullanılarak ifade edildiği ve bu kelimelerin ne kadar sıklıkla kullanıldığını belirlemek hedeflenmektedir. Şekil 3'te Instagram markasının kelime bulutu yer almaktadir. 


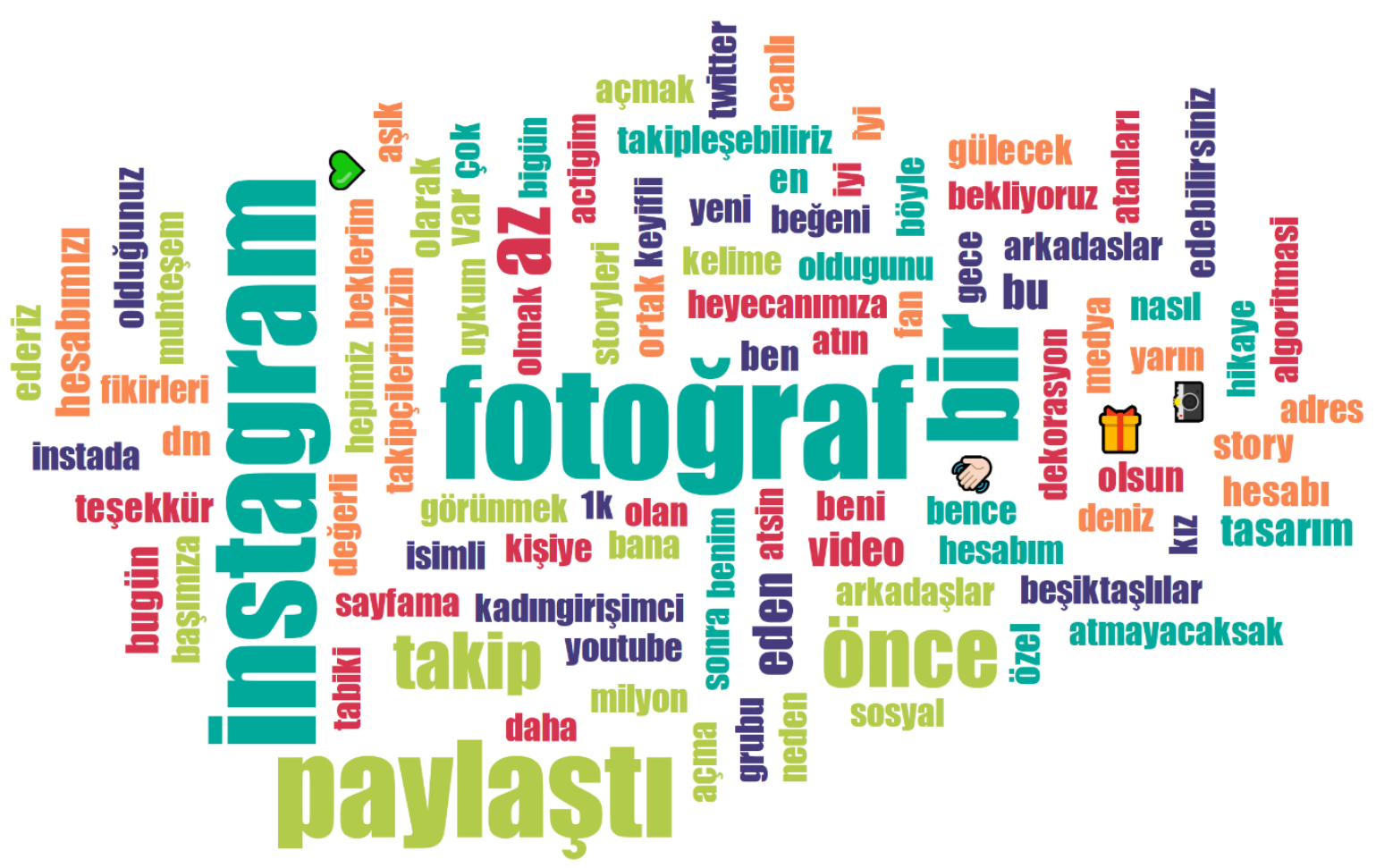

Şekil 3. Instagram Markasının Tüketicileri için Oluşturulan Kodlar ile İlişki Kurdukları Kelimelerin Frekans Değerlerine Göre Kelime Bulutu Görseli

Instagram markası için tüketicilerin en çok tekrar ettiği 10 kelime; fotoğraf ( $f=188)$, instagram $(\mathrm{f}=173)$, paylaştı $(151)$, bir $(\mathrm{f}=140)$, önce $(\mathrm{f}=92)$, az $(\mathrm{f}=84)$, takip $(\mathrm{f}=64)$, video $(17)$, hesabımız $(\mathrm{f}=16)$ ve story $(\mathrm{f}=10)$ olarak belirlenmiştir. Tüketicilerin marka aşkıyla ilgili kodlar ile ilişki kurduğu kelimelerin frekans değerleri parantez içinde belirtilmiştir. Parantez içinde belirtilen frekans değerleri, kelimelerin o sayı kadar tweetler içerisinde vurgulandığını ifade etmektedir. Kod listesinde yer alan kodlar tweetlerin içeriğine göre kodlanmıştır. Kelime bulutu incelendiğinde bir aşk markası olan Instagram'ın tüketicilerin kalbinde yer almayı başardığı şeklinde değerlendirme yapılabilmektedir. Görselliği ile tanınan Instagram markasının kelime bulutu görselinde en çok tekrarlanan kelimenin fotoğraf olduğu görülmektedir. Fotoğraf çekmeyi/çekilmeyi, çekilen fotoğrafları paylaşmayı seven ve bu durumu sağlayan program olması müşterileri için bir tercih sebebidir. Bir aşk markası olan Instagram, müşteri memnuniyetini sağlayarak tüketicilerin tercih edilen markası haline gelmiştir. Sonuç olarak, Instagram markası bu tehdit içerikli Covid-19 pandemisi durumundan olumsuz yönde etkilenmediğini göstermektedir.

\subsection{Netflix}

Uygulanacak kelime bulutu analizi ile Netflix markasının tüketiciler perspektifinden Twitter'da hangi kelimeler kullanılarak ifade edildiği ve bu kelimelerin ne kadar sıklıkla kullanıldığını belirlemek hedeflenmektedir. Şekil 4'de Netflix markasının kelime bulutu yer almaktadır. 


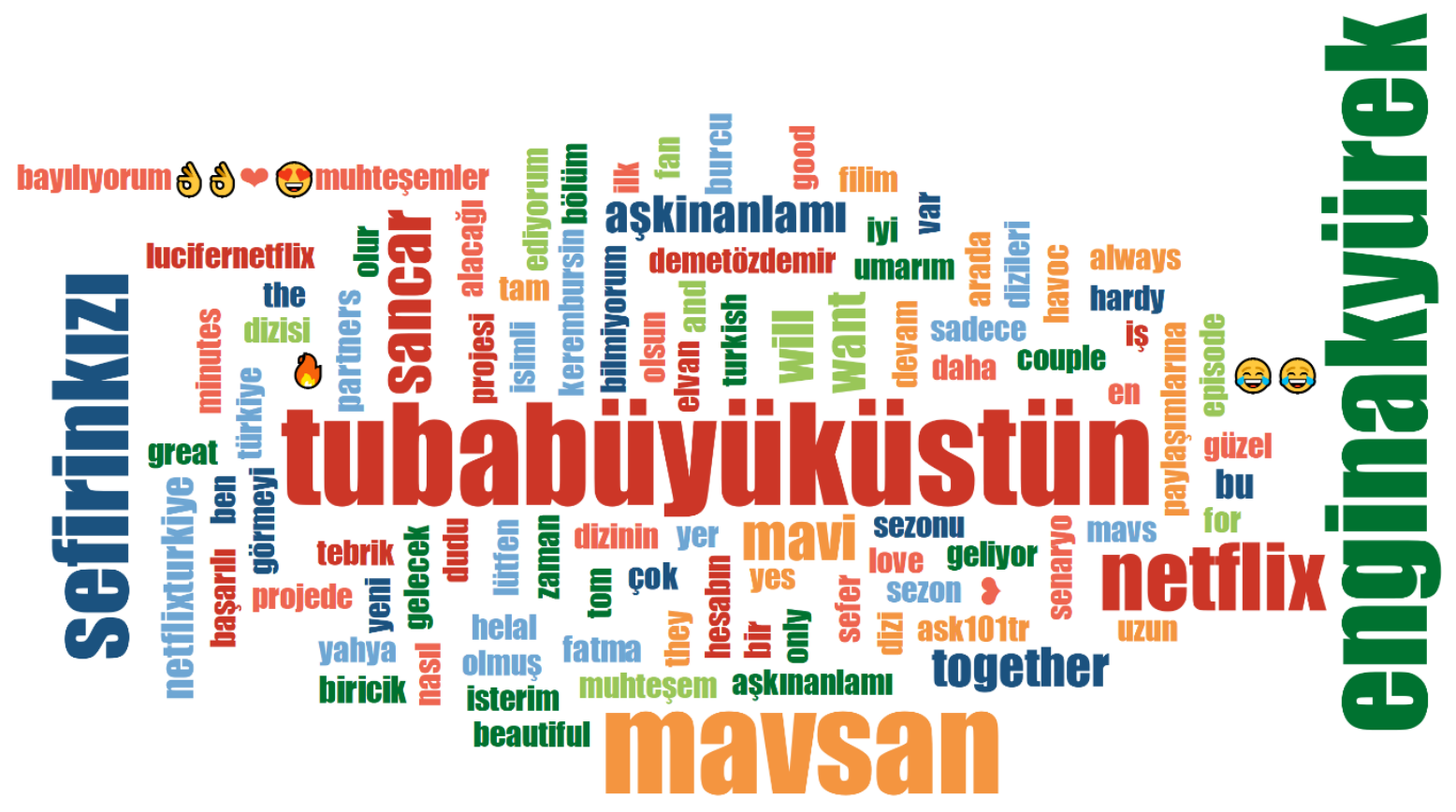

Şekil 4. Netflix Markasının Tüketicileri için Oluşturulan Kodlar ile İlişki Kurdukları Kelimelerin Frekans Değerlerine Göre Kelime Bulutu Görseli

Netflix markası için tüketicilerin en çok tekrar ettiği 10 kelime; tubabüyüküstün ( $\mathrm{f}=908)$, enginakyürek ( $f=907)$, mavsan ( $f=875)$, sefirinkızı $(f=590)$, netflix ( $f=508)$, sancar $(f=307)$, mavi $(\mathrm{f}=264)$, aşkinanlamı ( $\mathrm{f}=159)$, netflixtürkiye $(\mathrm{f}=94)$ ve fatma ( $\mathrm{f}=33)$ olarak belirlenmiştir. Tüketicilerin marka aşkıyla ilgili kodlar ile ilişki kurduğu kelimelerin frekans değerleri parantez içinde belirtilmiştir. Parantez içinde belirtilen frekans değerleri, kelimelerin o sayı kadar vurgulandığını ifade etmektedir. Kod listesinde yer alan kodlar tweetlerin içeriğine göre kodlanmıştır. Kelime bulutu incelendiğinde bir aşk markası olan Netflix'in tüketicilerin kalbinde yer almayı başardığı şeklinde değerlendirme yapılabilmektedir. En çok tekrar edilen kelimelerden biri olan 'mavsan' Sefirin Kızı dizisinde başrol karakterlerine ait olan isimlerin (Mavi-Sancar) kısaltılmasıdır. İncelenen tweetler kapsamında Sefirin Kızı dizisiyle ilgili atılan tweetlerin çok tekrarlanmasının sebepleri, analizin yapıldığı tarihlerde dizinin final yapacağı haberlerin Twitterda yayılması, dizinin fan ekibi ve dizinin izleyicileri tarafından Netflix'te dizinin devam etmesi için hashtag (etiket) açılması sıralanabilmektedir. Bir aşk markası olan Netflix, tüketicileri ile başarılı bir etkileşim sağlayarak müşteri memnuniyetini sağlamıştır. Sonuç olarak, Netflix markası bu tehdit içerikli Covid-19 pandemisi durumundan olumsuz yönde etkilenmediğini göstermektedir.

\subsection{Kod Bulutu}

Kod bulutları, en sık atanan kodları sözcük bulutları olarak görselleştirmek için kullanılan bir analiz tekniğidir. Kod bulutu, bir çalışmadaki tüm belgelerde kullanılan kodları temsil etmektedir (Code Cloud I MAXQDA). Kod kelimelerinin belirlenmesi için marka aşkı ile ilgili literatür taraması yapılmış ve literatürde marka aşkı ile sık kullanılan anahtar kelimeler belirlenmiştir. Literatürden seçilen kelimeler; müşteri memnuniyeti (Song vd., 2019; Ghorbanzadeh ve Rahehagh, 2020; Özbek vd., 2017), markaya duyulan güven (Onurlubaş ve 
Altunışık, 2019; Song vd., 2019; Aydın, 2017), aşk (Çavuşoğlu ve Demirbağ, 2020; Song, 2019), marka sadakati (Çavuşoğlu ve Demirbağ, 2020; Özmen ve Kocakuş, 2020; Aşkın ve İpek, 2016; Le, 2020), tercih edilen marka (Aytekin ve Taştepe, 2020), sevilen marka (Wang vd., 2019; Palusuk vd., 2019; Fernandes ve Inverneiro, 2020), ve marka tutkusu (Heinrich vd., 2012) şeklindedir. Kodlamada geçen diğer yedi kelime Twitter'da konuyla ilgili ulaşılan güncel beş yüz tweet içerisindeki mesaj ifadelerine göre belirlenmiştir. Toplamda marka aşkı kelimesi hariç on dört kelime belirlenmiştir. Kod bulutunda kodlar arası etkileşimi görmek mümkün olduğu için kavramlar arası bağlantıyı oluşturmak da mümkün olmaktadır. Kavramlar arası bağlantıyı kavrayabilmek için kodların frekans değerlerine bakılması gerekmektedir. Şekil 5'te aşk markalarında kullanılan kodların kod bulutu görseli yer almaktadir.

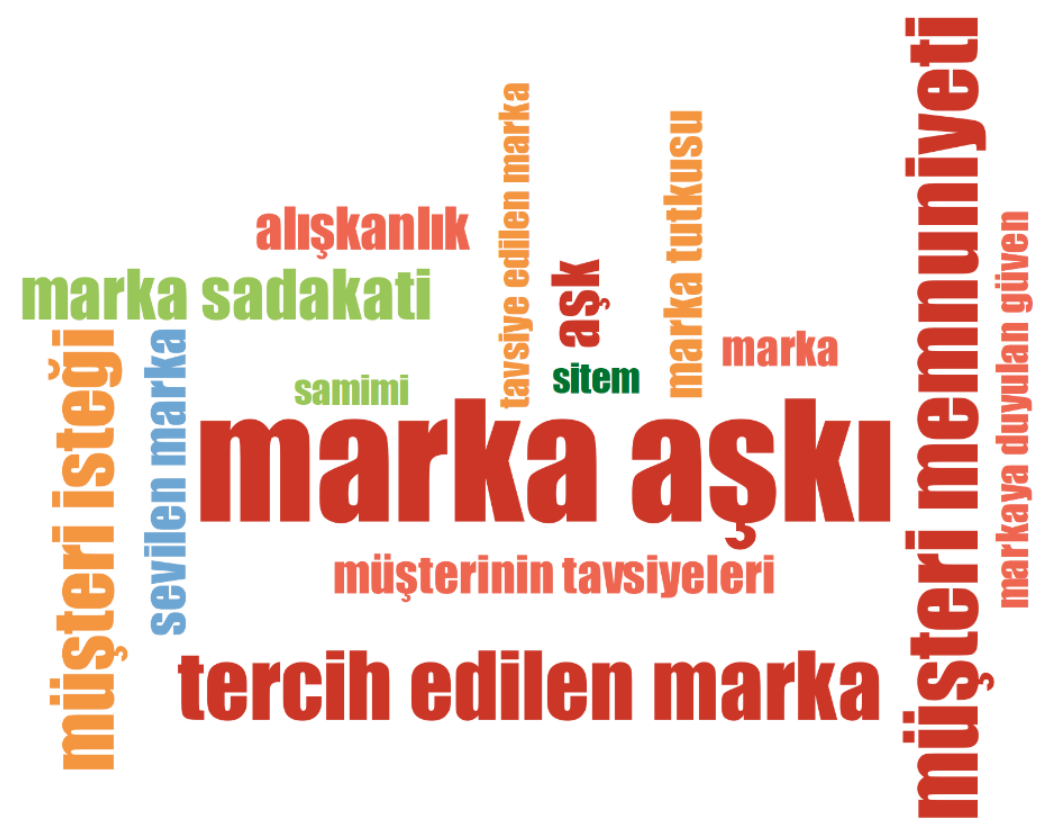

\section{Şekil 5. Aşk Markalarında Kullanılan Kodların Kod Bulutu Görseli}

Marka aşkı ile ilgili literatür taramasının ardından ilgili anahtar kelimeler seçilerek kodlar oluşturulmuştur. Bazı kodlar ise tweetlerin içeriğine göre belirlenmiştir. Örneğin, müşteri isteği kodu kapsamında Erikli markasına tüketicilerin attıkları tweetlerin pek çoğunda mor şişe talebi öne çıkmaktadır. Nescafe markası için gold kahve makinası talepleri, Netflix markasında dizi istekleri, Instagram markasında ise tüketicilerin sayfa takip istekleri yoğunluktadır. Kod listesine seçilen sitem kelimesi ise şikayet amaçlı kullanılmamıştır. Örneğin, Netflix markasına ait sitemli tweetlerin içeriğinde dizilerin analizleri ve dizide yer alan oyuncular hakkında eleştirmeler veya tavsiyeler bulunmaktadır. Anahtar kelimeler, MAXQDA 2020 programinda yer alan kodlar sistemine eklenmiştir. Her eklenen kod kodlar sisteminin içerisinde birikmektedir. Kod bulutu, 4 markaya ait kodların toplam frekans değerini vermektedir. Diğer bir ifade ile her bir kodun dört marka için toplam tweet sayısında $(\mathrm{n}=500,500 \times 4)$ ne kadar kodlandığını temsil etmektedir. Böylece marka aşkına yakın frekans değeri taşıyan kodlar, marka aşkı kapsamında kavramlar arası bağlantıyı oluşturmaktadır. Marka aşkı için oluşturulan kod listesinin frekans değerleri; marka aşkı 
( $\mathrm{f}=707)$, müşteri memnuniyeti $(\mathrm{f}=334)$, tercih edilen marka ( $\mathrm{f}=314)$, müşteri isteği $(\mathrm{f}=253)$, marka sadakati $(\mathrm{f}=167)$, aşk $(\mathrm{f}=140)$, alışkanlık $(\mathrm{f}=109)$, sevilen marka $(\mathrm{f}=98)$, marka tutkusu $(\mathrm{f}=73)$, müşterinin tavsiyeleri $(\mathrm{f}=75)$, marka $(\mathrm{f}=45)$, markaya duyulan güven $(\mathrm{f}=38)$, tavsiye edilen marka ( $\mathrm{f}=14)$, sitem $(\mathrm{f}=14)$, samimi $(\mathrm{f}=9)$ şeklinde oluşmuştur. Bu değerler ışığında marka aşkı kavramına en yakın kavramların müşteri memnuniyeti ve tercih edilen marka olduğu görülmektedir. Tüketicilerin memnun oldukları markalara âşı oldukları değerlendirmesinin yapılması analiz sonucunda ortaya konulabilmektedir. Müşteri memnuniyetini yakalama ve sürdürülebilir kılma da en önemli konu müşteri güvenini sağlayarak müşteri ile etkili bir iletişim kurabilmektir. Ziraat Bankası ve Trendyol markaları aşk markası listesindeki yerlerini muhafaza edememişlerdir. Tweetlerde geçen yoğun şikayetler ise bu sonucu destekleyen en etkili gerçekliklerdir. Aynı zamanda tüketiciler markanın diğer tüketiciler tarafından da tercih edilen marka olmasına özen göstermektedir. Müşteri isteği kavramının da frekans değeri marka sadakati kavramından yüksek çıkmıştır. Bunun sebebi, aşk markalarının tüketicilerin seslerine kulak vermesidir. Örneğin, Netflix içerikli tweetler incelendiğinde görülmektedir ki tüketicilerin markadan isteği, Sefirin Kızı dizisinin Netflix platformuna transfer edilmesi yönündedir. Markanın bunun üzerine çalışma yapması neticesinde istek yerine geldiği taktirde markaya duyulan aşkın artacağı öngörülmektedir.

\subsection{Kod Dağıtım Modeli}

Çalışmanın ana temasının marka aşkı olması sebebiyle analiz edilen dört marka arasında en çok hangi markada marka aşkı kodunun kodlandığını tespit etmek amacıyla kod dağıtım modeli analizi yapılmıştır. Böylece analizi yapılan aşk markalarının kendi aralarında da bir sıralama yapmak mümkün olmuştur. Şekil 6 'da kod dağıtım modelinin görseli yer almaktadir.

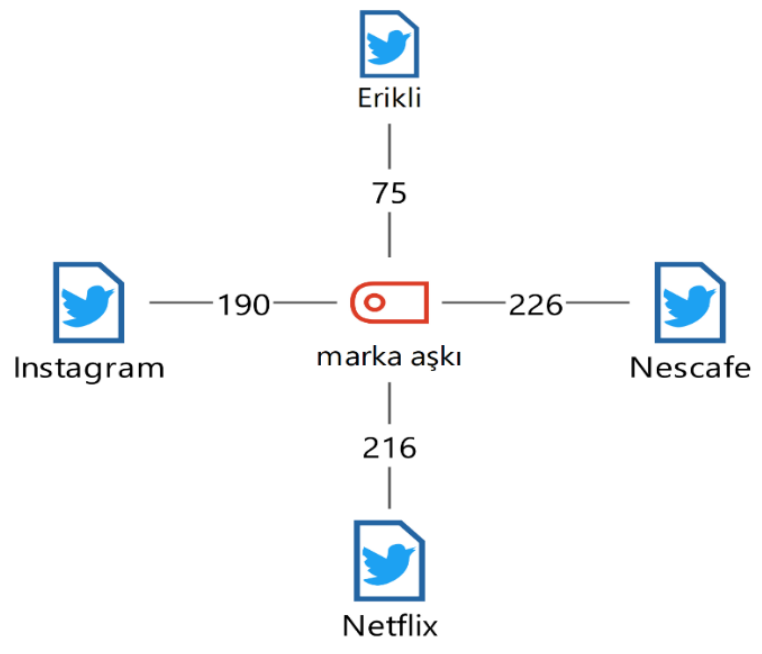

\section{Şekil 6. Aşk Markalarının Kod Dağıtım Modeli}

Erikli markasının marka aşkı kodunun frekans değeri 75, Instagram markasının marka aşkı kodunun frekans değeri 190, Nescafe markasının marka aşkı kodunun frekans değeri 226 ve Netflix markasının marka aşkı kodunun frekans değeri 216'dır. Frekans değerleri, aşk markalarının belirtilen sayı kadar marka aşkı koduyla vurgulandığını ifade etmektedir. Frekans değerlerine göre incelenen dört aşk markasının sıralaması yapıldığında listenin ilk 
sırasında yer alan marka Nescafe olmuştur ve ardından Netflix, Instagram ve Erikli şeklinde markalar sıralanmıştır. Pandemi döneminin getirdiği koşullar çerçevesinde Nescafe, Netflix ve Instagram'ın frekans değerleri Erikli markasına kıyasla daha yüksek çıkmıştır. İnsanlar evlerinde hayatlarını devam ettirmek zorunda kaldıkları için tek aktiviteleri film izlemek, sosyal medyada vakit geçirmek veya yemek yemek/yapmak gibi faaliyetler olmuştur. Analiz sonucunda da en yüksek frekans değerini Nescafe ve Netflix almıştır. Pandemi dönemlerinde film eşliğinde, canlı derslerde uyuklamamak veya home ofis çalışanları için Nescafe iyi bir seçenek olmaktadır. Dışarıda aktivite yapılabilecek yerlerin kapalı olması nedeniyle Netflix'e üye olup film izleyerek vakit geçirmek de diğer iyi bir seçenektir. Dolayısıyla yeni dönemin yeni aşk markası Netflix seçilmiştir. Üçüncü sırada yer alan Instagram ise, insanların birbirlerine meydan okuyarak destek oldukları bir platform olması sebebiyle pandemiye rağmen değişmeyen bir aşk markasıdır. Sonuç olarak, pandemi döneminde birçok marka farklı tehditlerle karşı karşıya kalmıştır. Bu tehditleri fırsata çeviren markalar varlıklarını başarıyla sürdürmektedir. Seçilen aşk markaları da krizi fırsata çeviren markalar arasında yer almaktadır.

\section{SONUÇ, ÖNERILER VE KISITLAR}

2019 yılının Aralık ayında Çin'in Wuhan bölgesinde ortaya çıkan ve çok kısa bir süre içerisinde tüm dünyayı etkisi altına alan Corona virüsü, hayatın her alanında küresel ölçekte etkiler yaratmıştır. Hem toplumsal hem de ekonomik anlamda büyük değişimlerin yaşandığ1 bu zaman dilimi pandemi yılı olarak adlandırılmıştır. Bu dönem tüm dünyada görülen virüse bağlı salgın hastalık, ciddi sayıda insan ölümlerinin yaşandığı ve insanların sosyal yaşamlarının radikal değişimlere uğradığı bir zorunlu kapanma dönemidir. Bu süreçte insanların 'hayat eve sığar', 'evde kal' ve 'evde hayat var' gibi sloganların oluşturduğu telkinler ve yasal düzenlemelerle zorunlu ihtiyaçları dışında evlerinden çıkmamaları sağlanmaya çalışılmıştır. İnsan hayatında meydana gelen bu değişimlere paralel olarak tüketicilerin yaşam tarzları da değişime uğramıştır. Pandemi sürecinde, yasaklar ve karantina şartları gereği evde geçirilen süre artmış, ihtiyaçlar kapsamında yapılan alışverişler genel olarak temel ihtiyaçları içermiştir. İnsanlar evlerinde kendi kendilerine yetebilecekleri, ihtiyaçlarını karşılamanın farklı yollarını öğrenmek zorunda kaldıkları bir yaşam tarzına yönelmişlerdir.

$\mathrm{Bu}$ çalışmada tüketiciler perspektifinden aşk markaları Covid-19 pandemisi süreci kapsamında ele alınmıştır. Covid-19 pandemisi ve aşk markaları bağlamında literatürde yapılan çalışmalar incelenmiş ve Covid-19 pandemisi sürecinde tüketicilerin marka aşkına bakış açılarını yansıtacak herhangi bir çalışmaya rastlanmamıştır. Literatüre, bu eksikliği de giderecek bir katkı sağlamak amacıyla araştırma planı oluşturulmuştur. Araştırmanın sinırlılıklarından biri MAXQDA 2020 programından kaynaklanmaktadır. Program, araştırma veri kaynağı olarak belirlenen Twitter verilerine son bir haftalık süreçte ulaşım imkanı sunmaktadır. Bu kısıt Twitter üzerinden daha eski verilere ulaşmayı engellemiştir ve değerlendirmeler son bir haftalık veriler üzerinden gerçekleştirilmiştir. Diğer bir sınırlılık ise, aşk markalarının, amaçlı örnekleme yöntemine göre seçilmesidir.

Çalışmanın amacı, Covid-19 pandemisi öncesi ve sonrası süreçte aşk markaları listesini değerlendirmek, pandemiye rağmen değişen, değişmeyen veya listeye yeni eklenen aşk markalarında meydana gelen değişimlerin analizini yapmaktır. Bu amaç kapsamında nitel 
araştırma yöntemlerinden biri olan içerik analizi, MediaCat tarafından 2019 ve 2020 yılında seçilen aşk markaları üzerinde yapılmıştır. İçerik analizi ile Twitter üzerinden kelime bulutu, kod bulutu ve kod dağıtım modeli analizleri yapılmıştır. Mediacat Dergisi Aşk Markaları Listesi kapsamında Covid-19 pandemisine rağmen değişmeyen aşk markaları Erikli, Nescafe ve Instagram olurken, Covid-19 pandemisiyle tüketicilerin yeni yaşam koşullarına göre şekillenen aşk markası Netflix olmuştur. Analizi yapılan bu dört aşk markası, Covid-19 pandemisi gibi bir tehdidi müşteri memnuniyeti ile fırsata çevirmeyi başarmıştır.

Bu konuda çalışmak isteyen araştırmacılara, bundan sonraki yıllarda yeni belirlenecek aşk markaları listesine göre farklı değişkenler kapsamında analizler yapmaları önerilebilir. Ayrıca bu çalışmanın örneklemini farklı nitel araştırma yöntemlerinden birini kullanarak da belirleyebilirler. Kod bulutu oluşturulması sonucunda, araştırma kapsamında, tüketicilerin memnun oldukları ve diğer tüketiciler tarafından da tercih edilen markalara âşık oldukları görülmüştür. Dolayısıyla marka aşkıyla ilişkisi olan farklı kavramların değişken olarak kullanıldığı ve tercih edilen markalar üzerinde başka bir örneklem ile veya başka bir araştırma deseni ile de literatüre katkı sağlanması önerilebilir. Ayrıca marka aşkı ve marka nefreti gibi içerik olarak birbirine zıt kavramların uygulamada karşılaştırıldıkları çalışmalar da yürütülebilir. 


\section{KAYNAKÇA}

Aktuğlu, I.K. (2016). Marka Yönetimi: Güçlü ve Başarılı Markalar İçin Temel İlkeler. İstanbul: İletişim Yayınları.

Albert, N., Merunka, D. ve Valette-Florence, P. (2008). When Consumers Love Their Brands: Exploring the Concept and its Dimensions. Journal of Business Research, 61, 10621075.

AMA (American Marketing Association). (2017). What is Marketing? - The Definition of Marketing - AMA. (Erişim: 10.03.2021).

Arslan, İ. ve Karagül, S. (2020). Küresel Bir Tehdit (COVID-19 Salgını) ve Değişime Yolculuk. Üsküdar Üniversitesi Sosyal Bilimler Dergisi, 10, 1-36.

Aşkın, N.ve İpek, İ. (2016). Marka Aşkının Marka Deneyimi ile Marka Sadakati Arasındaki İlişkiye Aracılık Etkisi. Ege Akademik Bakış, 16(1), 79-94.

Aydın, H. (2017). Marka Güveni, Farkındalığı ve Benlik İmaj Uyumunun Marka Bağlılı̆̆ına Etkisinde Marka Aşkının Aracılık Rolü. Ege Akademik Bakış, 17(2), 281-294.

Aytekin, P. ve Taştepe, Ö. (2020). Samsung Markası Üzerinde Marka Aşkının, Marka Özgünlüğü ve Marka Tercihi Arasındaki Aracılık Etkisinin İncelenmesi. İşletme Araştırmaları Dergisi, 12(3), 2846-2863.

Ayvaz, S. (2017). Aşkın Tüketim Kültürü Üzerinden Yeniden Anlamlandırılması: Markafoni Örneği. Ankara Üniversitesi İLEF Dergisi, 4(1): 149-170.

Bairrada, C.M., Coelho, A. ve Lizantes, V. (2019). The impact of brand personality on consumer behavior: the role of brand love. Journal of Fashion Marketing and Management: An International Journal, 23(1), 30-47.

Budak, F. ve Korkmaz, Ş. (2020). COVID-19 Pandemi Sürecine Yönelik Genel Bir Değerlendirme: Türkiye Örneği. Sosyal Araştırmalar ve Yönetim Dergisi, 1, 62-79.

Can, E. (2007). Marka ve Marka Yapılandırma. Marmara Üniversitesi İktisadi ve İdari Bilimler Dergisi, 22(1): 225-237.

Carroll, B.A. ve Ahuvia, A.C. (2006). Some Antecedents and Outcomes of Brand Love. Marketing Letters, 17(2), 79-89.

Code Cloud I MAXQDA. (Erişim: 03.05.2021).

Çakıroğlu, K.I., Pirtini, S. ve Çengel, Ö. (2020). COVID-19 Sürecinde ve Post-Pandemi Döneminde Yaşam Tarzı Açısından Tüketici Davranışlarının Değişen Eğilimi Üzerine Kavramsal Bir Çalışma. İstanbul Ticaret Üniversitesi Sosyal Bilimler Dergisi, 19(37), 81-103.

Çavuşoğlu, S. ve Demirbağ, B. (2020). Benlik İfade Eden Marka, Marka Aşkı, Pozitif Ağızdan Ağıza İletişim ve Marka Sadakati Arasındaki İlişkinin İncelenmesi: Paketlenmiş Ürün Kategorisinde Bir Araştırma. Atatürk Üniversitesi İktisadi ve İdari Bilimler Dergisi, 34(3), 1065-1087. 
Deniz, A.K. (2020). COVID-19 Salgını Sürecinde Dijitalleşen Eğlence Anlayışı: Çevrim İçi Konserler. Stratejik ve Sosyal Araştırmalar Dergisi, 4(2), 191-206.

Duygun, A. (2020). COVID-19 Pandemisi Sırasında Tüketicilerin Yaşam Tarzlarının Değerlendirilmesi. International Academic Journal, 4(1), 232-247.

Edman, H. (2010). Twittering to the top: a content analysis of corporate tweets to measure organization-public relationships. Louisiana State University.

Fernandes, T. ve Inverneiro, I. (2020). From fandom to fad: are millennials really engaged with and loyal to their loved brands on social media?. School of Economics and Management, 1-15.

Ghorbanzadeh, D. ve Rahehagh, A. (2020). Emotional brand attachment and brand love: the emotional bridges in the process of transition from satisfaction to loyalty. Rajagiri Management Journal, 1-23.

Gürbüz, S. ve Şahin, F. (2018). Sosyal Bilimlerde Araştırma Yöntemleri Felsefe-YöntemAnaliz. Ankara: Seçkin Yayıncılık.

Heinrich, D., Albrecht, C.M. ve Bauer, H.H. (2012). Love actually? Measuring and exploring consumers brand love. Consumer-Brand Relationships-Theory and Pratice, 137-150.

İslamoğlu, A.H. ve Fırat, D. (2016). Stratejik Marka Yönetimi. İstanbul: Beta Basım A.Ş.

Jansen, B.J., Zhang, M., Sobel, K. ve Chowdury, A. (2009). Twitter Power: Tweets as Electronic Word of Mouth. Journal of the American Society for Information Science and Technology, 60(11), 2169-2188.

Joshi, R. ve Garg, P. (2021). Role of brand experience in shaping brand love. International Journal of Consumer Studies, 45(2), 259-272.

Karataş, Z. (2015). Sosyal Bilimlerde Nitel Araştırma Yöntemleri. Manevi Temelli Sosyal Hizmet Araştırmaları Dergisi, 1(1), 62-80.

Kumar, S., Dhir, A., Talwar, S., Chakraborty, D. ve Kaur, P. (2021). What drives brand love for natural products? The moderating role of household size. Journal of Retailing and Consumer Services, 58, 1-10.

Le, M.T.H. (2020). The Impact of Brand Love on Brand Loyalty: The Moderating Role of SelfEsteem, and Social Influences. Spanish Journal of Marketing - ESIC, 1-24.

maxqda.com. (Erişim: 14.05.2021).

mediacat.com. (Erişim: 13.05.2021).

mediacat.com. (Erişim: 15.03.2021).

Onurlubaş, E. ve Altunışık, R. (2019). Marka Güveninin Satın Alma Niyeti Üzerindeki Etkisinde Marka Aşkının Aracılık Rolü. Kesit Akademi Dergisi, 18, 116-135.

Özbek, V. ve Doğan, O. (2018). Akıllı Telefon Markalarına Yönelik Marka Aşkı Düzeyleri Farklılık Gösterir Mi? Üniversite Öğrencileri Üzerinde Bir Araştırma. PressAcademia Procedia, 7: 268-271. 
Özbek, V., Kutbay, A.Y., Doğan, Ö. ve Kulahli, A. (2017). Antecedents of Brand Love: A Research on Bank Customers. PressAcademia Procedia, 3(1), 609-619.

Özmen, A. ve Kocakuş, Z.G. (2020). Kuşaklar Bağlamında Marka Aşkının Marka Sadakatine Etkisi: Afyonkarahisar'da Bir Araştırma. İşletme Araştırmaları Dergisi, 12(4), 43234339 .

Palusuk, N., Koles, B. ve Hasan, R. (2019). All you need is brand love': a critical review and comprehensive conceptual framework for brand love. Journal of Marketing Management, 35, 97-129.

Ramadan, Z.B. (2016). Brand-Brand Relational Moments. Journal of Brand Management, 26: 705-716.

Roberts, K. (2005). Lovemarks: The Future Beyond Brands. Powerhouse Books.

Sammut-Bonnici, T. (2015). Brand and Branding. Wiley Encyclopedia of Management, 1-3.

Song, H., Wang, J. ve Han, H. (2019). Effect of imag, satisfaction, trust, love, and respect on loyalty formation for name-brand coffee shops. International Journal of Hospitality Management, 79, 50-59.

Stemler, S.E. (2015). Content Analysis. Emerging Trends in the Social and Behavioral Sciences, 1-14.

Sternberg, R.J. (1986). A Triangular Theory of Love. Psychological Review, 93(2), 119-135.

Şayan, A. (2020). Marka Bağlılığı Yaratmada Sosyal Medyanın Rolü: Lovemark's Örnekleri Üzerine Bir Araştırma. Uluslararası Ders Kitapları ve Eğitim Materyalleri Dergisi, 3(1), 319-342.

tr.wikipedia.org. (Erişim: 13.05.2021).

Tran, T.P., Muldrow, A. ve Bich Ho, K.N. (2020). Understanding Drivers of Brand Love - The Role of Personalized ads on Social Media. Journal of Consumer Marketing, 38(1), 114 .

Wang, Y.C., Qu, H. ve Yang, J. (2019). The formation of sub-brand love and corporate brand love in hotel brand portfolios. International Journal of Hospitality Management, 77, 375-384.

Williams, W., Parkes, E.L. ve Davies, P. (2013). Wordle: A method for analysing MBA student induction experience. The International Journal of Management Education, 11(1), 44-53.

Zengin, A.Y. ve Aladağ, B. (2018). Social Media Driven Brand Love: An Investigation on Turkish Customers. İnternet Uygulamaları ve Yönetimi Dergisi, 9(1), 19-42.

Zhang, H., Xu, H. ve Gursoy, D. (2020). The effect of celebrity endorsement on destination brand love: A comparsion of previous visitors and polential tourists. Journal of Destination Marketing \& Management, 17, 1-14. 
Zhang, Y., Zhang, J. ve Sakulsinlapakorn, K. (2020). Love Becomes Hate? Or Love is Blind? Moderating Effects of Brand Love Upon Consumers' Retaliation Towards Brand Failure. Journal of Product \& Brand Management, 1-18.

Zhou, F., Mou, J., Su, Q. ve Jim Wu, Y.C. (2020). How does consumers' Perception of Sports Stars' Personel Brand Promote Consumers' brand love? A mediation model of global brand equity. Journal of Retailing and Consumers Services, 54, 1-10. 